\title{
South African small and medium-sized enterprise owners' intention to implement an environmental management system
}

\begin{tabular}{|c|c|}
\hline \multicolumn{2}{|c|}{$\begin{array}{l}\text { Authors: } \\
\text { Fredrika (Miemie) W. Struwig } \\
\text { Riyaadh Lillah }{ }^{1}\end{array}$} \\
\hline \multicolumn{2}{|c|}{$\begin{array}{l}\text { Affiliations: } \\
{ }^{1} \text { Department of Business } \\
\text { Management, Nelson } \\
\text { Mandela Metropolitan } \\
\text { University, South Africa }\end{array}$} \\
\hline \multicolumn{2}{|c|}{$\begin{array}{l}\text { Corresponding author: } \\
\text { Miemie Struwig, } \\
\text { miemie.struwig@nmmu. } \\
\text { ac.za }\end{array}$} \\
\hline \multicolumn{2}{|c|}{$\begin{array}{l}\text { Dates: } \\
\text { Received: } 15 \text { Sept. } 2016 \\
\text { Accepted: } 03 \text { May } 2017 \\
\text { Published: } 28 \text { June } 2017\end{array}$} \\
\hline \multicolumn{2}{|c|}{$\begin{array}{l}\text { How to cite this article: } \\
\text { Struwig, F.W. \& Lillah, R., 2017, } \\
\text { 'South African small and } \\
\text { medium-sized enterprise } \\
\text { owners' intention to } \\
\text { implement an environmental } \\
\text { management system', } \\
\text { Southern African Journal of } \\
\text { Entrepreneurship and Small } \\
\text { Business Management 9(1), } \\
\text { a104. https://doi.org/ } \\
\text { 10.4102/sajesbm.v9i1.104 }\end{array}$} \\
\hline \multicolumn{2}{|c|}{$\begin{array}{l}\text { Copyright: } \\
\text { (C) 2017. The Authors } \\
\text { Licensee: AOSIS. This } \\
\text { is licensed under the } \\
\text { Creative Commons } \\
\text { Attribution License. }\end{array}$} \\
\hline \multicolumn{2}{|l|}{ Read online: } \\
\hline 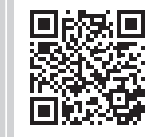 & $\begin{array}{l}\text { Scan this QR } \\
\text { code with your } \\
\text { smart phone or } \\
\text { mobile device } \\
\text { to read online. }\end{array}$ \\
\hline
\end{tabular}

Background: Environmental problems present the most complex and important managerial challenges of the 21st century. Most businesses have responded to these environmental problems by adopting an environmental management system.

Aim: This article investigates South African small and medium-sized enterprise (SME) owners' intentions to implement an environmental management system based on the theory of planned behaviour.

Setting: Although large businesses are clearly of interest with respect to their environmental management, especially given their prominence in many of the most environmentally impactful sectors, the relative neglect of the environmental management of SMEs is disconcerting, given their overall importance in most economies. In addition, very little research used the theory of planned behaviour to empirically test SME owners' intentions, to implement an environmental management system.

Method: A quantitative survey was used to collect primary data from 326 SME owners by a structured questionnaire.

Results: Regression analysis results confirmed the influence of SME owners' attitudes towards an environmental management system and pro-environmental norms on their intention to implement an environmental management system. Perceived behavioural control, however, did not significantly influence the SME owners' intention to implement an environmental management system.

Conclusion: These findings provide valuable insights into the implementation of environmental management systems among South African SMEs. The theory of planned behaviour also seems to be an appropriate means to investigate the intentions of SMEs to implement an environmental management system.

\section{Introduction}

\section{Background}

Given growing global concerns about the depletion of natural resources and reductions in biodiversity, understanding why and how businesses engage in environmental management is of increasing interest and importance to both academics and practitioners (Dunphy, Griffiths \& Benn 2007; Holliday, Schmidheiny \& Watts 2002; Laszlo 2003). Most businesses have responded to the demand to address environmental issues by implementing environmental management systems (Sanchez-Medina, Romero-Quintero \& Sosa-Cabrera 2014). Darnall, Jolley and Handfield (2008) define an environmental management system as a collection of internal policies, assessments, plans and implementation actions. An environmental management system affects the business as a whole and its relationships with the natural environment.

The responsibility of responding to environmental issues is not limited to government and large businesses. In most economies, small and medium-sized enterprises (SMEs) are the largest contributors to economic activity (Brammer, Hoejmose \& Marchant 2012; Klewitz \& Hansen 2013). SMEs in South Africa have been identified as an important catalyst for economic growth. There are approximately 2.8 million SMEs in the country, contributing about $60 \%$ of the total employment. It is also estimated that no less than $90 \%$ of new jobs will be created in SMEs by 2030 (Groepe 2015:5). Although a single SME might not represent a substantial threat to the natural environment, given the prominence of these businesses in the economy, SMEs could have a larger collective impact on the environment than large businesses (Brammer et al. 2012). 
It is therefore just as important for SMEs to address environmental concerns.

Compared with large businesses, SMEs operate differently and face disparate challenges when implementing an environmental management system (Bos-Brouwers 2010; Brammer et al. 2012). According to Boiral, Baron and Gunnlaugson (2014), SMEs lack knowledge of their environmental impacts, and their cultural disposition of resistance to self-regulation and government intervention makes them less likely to implement an environmental management system. The lack of resources in SMEs might also play a deciding role in their choosing whether or not to implement an environmental management system. Brammer et al. (2012) further suggest that their informal structure, and the fact that SMEs are owner-managed, places more emphasis on personal choice and commitment in respect of environmental management.

In this article, the commitment to implement an environmental management system is associated with the underlying world views, abilities and psychological predispositions (to act in a particular way) of SME owners (Boiral et al. 2014). These psychological predispositions towards environmental management system implementation are captured by the SME owner's attitude towards an environmental management system, pro-environmental norms (PN) and perceived behavioural control (PBC) and are based on Ajzen's (1991) theory of planned behaviour. Thus, the aim of this study is to investigate South African SME owners' intentions to implement an environmental management system based on the theory of planned behaviour.

\section{Literature overview of the theory of planned behaviour}

The theory of planned behaviour is one of the most influential theories for explaining and predicting behaviour. The theory of planned behaviour (Ajzen 1991) is the successor to the theory of reasoned action, also known as the Fishbein behavioural intention model (Fishbein \& Ajzen 1975). Ajzen (1991) extended the theory of reasoned action to include PBC and to compensate for their model's limitation in accounting for behaviours where individuals lack control.

According to Ajzen (1991:181), the fundamental aspect of the theory of planned behaviour is behavioural intent that has been proven to be a good surrogate for behaviour. Steg and Vlek (2009) claim that the theory of planned behaviour is better at explaining behaviours that have high behavioural costs or strong behavioural constraints. Another advantage of this model is its specificity (Chao 2012; Monroe 2003). In other words, the theory of planned behaviour is more suited to examining specific environmental behaviours rather than a broad range of such behaviours. However, a number of studies using the theory to explain a range of environmental behaviours have emerged (Chao 2012). The theory of planned behaviour was not developed specifically to assess environmental behaviour (Chao 2012). Nevertheless, it has been extensively applied to explain various environmental behaviours (such as recycling, water-saving, green consumer behaviour and reducing meat consumption) (Chao 2012; Steg \& Vlek 2009). In the workplace setting, Greaves, Zibarras and Stride (2013) used the theory of planned behaviour to explore three environment-related behaviours (switching off PCs, using videoconferencing for meetings, and recycling) of workers in the United Kingdom, and found support for the theory.

\section{Theoretical framework used in this study}

In this study, the focus is on the intentions of SME owners to implement an environmental management system. Four components based on the theory of planned behaviour were used in this study.

\section{Component 1: Intention to implement an environmental management system}

The intention to implement an environmental management system (INTENT) was defined as the degree of willingness to try, or how much of an effort an individual is planning to exert, and to implement an environmental management system (Ajzen 1991). Thus, this variable will deal with the extent to which SME owners agree that they intend to implement an environmental management system in the future.

Behavioural intent is dependent on the SME owners' attitude towards implementing an environmental management system (ATT), PN and PBC. (Ajzen 1991; Monroe 2003). It should also be noted that it is assumed that PBC could also influence actual behaviour. In addition, Ajzen (1991) asserted that attitude, social norms and PBC are correlated, and that the relative importance of these factors will differ across behaviours and situations.

\section{Component 2: Attitudes towards implementing an environmental management system}

An individual's attitude can be defined as the degree to which a person has a favourable or unfavourable evaluation or appraisal of the target behaviour and its associated consequences (Ajzen 1991; Cordano et al. 2010b; MartínPeña, Díaz-Garrido \& Sánchez-López 2010). In this article, the attitude of an SME owner towards an environmental management system is the degree to which the owner has a favourable or unfavourable evaluation or appraisal of implementing an environmental management system. In essence, this attitude will be determined by the ownermanager's evaluation of the benefits of implementing an environmental management system.

Psomas, Fotopoulos and Kafetzopoulos (2011) identified an improved market position, relationships with stakeholders and waste management as benefits of improved environmental performance. On the contrary, Worthington and Patton (2005) argued that businesses expect 
environmental actions to yield commercial benefits. Similarly, Nee and Wahid (2010) found that implementing the International Organization for Standardisation's (ISO) ISO 14001 environmental management system has a significant positive influence on SMEs' performance. McKeiver and Gadenne (2005) reported that improved working conditions were the most important benefit in their study, and that increased sales were the least important benefit. Similarly, Masurel (2007) stated that improved working conditions are the most important reason that SMEs invest in environmental measures. Dahlmann, Brammer and Millington (2008b) found that economic considerations such as cost reduction, risk mitigation and compliance with environmental legislation motivate business to adopt environmental management practices, especially among SMEs. Uhlaner et al. (2012) found that perceived financial benefits predict an SME's level of engagement in selected environmental management practices. Gadenne, Kennedy and McKeiver (2009) found that legislation results in general environmental awareness, which in turn increases SMEs' willingness to adopt environmental management practices. However, these authors warn that SME owners do not recognise the benefits arising from cost reductions. Brammer et al. (2012) found that SMEs perceive cost advantages and increased market share as key benefits of environmental management. In South Africa, Kehbila, Jurgen and Brent (2009) identified improved customer relations; competitiveness; relationships with authorities; and employee acceptance as key benefits of implementing an environmental management system. Empirical evidence of the influence of environmental attitudes on the adoption of environmental management practices in SMEs is provided by Cordano, Marhsall and Silverman (2010a) and Sanchez-Medina et al. (2014). These authors found that SME owners' attitudes towards environmental management practices positively influence the likelihood that their business would adopt such practices. It is proposed that the more positive the SME owner's attitude towards an environmental management system, the more likely he and/or she is to intend to implement one.

Based on the theoretical outline, the following hypothesis will be tested in this study:

$\mathbf{H}_{\mathbf{1}}$ : There is a positive relationship between SME owners' attitudes towards an environmental management system and their intention to implement such a system.

\section{Component 3: Pro-environmental norms}

Schwartz (1977) proposed what has been referred to as the 'norm-activation model of altruism', which deals with behaviours that go beyond self-interest and focus rather on helping others. Norms can be described as 'statements about how one ought to behave' (Dietz, Fitzgerald \& Shwom 2005:354). Norms can also be understood as the perceived expectations of important referent groups to perform certain behaviours, and the motivation to comply with these expectations (Ajzen 1991; Fielding, McDonald \& Louis 2008; Martín-Peña et al. 2010).
In relation to the environment, norms can be understood as the beliefs of an individual about how he and/or she is supposed to act towards the environment and the perceived social pressure to act in an environmentally friendly manner. PN thus include the rules and standards that are understood by members of a group, and that guide and/or constrain social behaviour without the force of laws (Fritsche et al. 2010). In this study, PN thus consist of personal norms and social norms in relation to protecting the environment. It is assumed that the stronger the personal and social norms to protect the environment, the greater the likelihood that the SME owner will intend to implement an environmental management system.

Very little of the research dealing with the implementation of environmental management systems in SMEs addresses the relationship between owners' $\mathrm{PN}$ and their environmental behaviours. Dief and Font (2010) found that managers' personal values predict environmental operations, but not environmental planning and organising. Lopez-Gamero, Claver-Cortes and Molina-Azorin (2011) found that voluntary norms, rather than environmental legislation, influence SME owners' perception of the environment as a competitive opportunity. Sanchez-Medina et al. (2014) reported that perceived social norms positively influence SME owners' PBC to undertake environmental measures. Thus, the following hypothesis will be tested in this study:

$\mathbf{H}_{2}$ : There is a positive relationship between SME owners' proenvironmental norms and their intention to implement such a system.

\section{Component 4: Perceived behavioural control}

Perceived behavioural control (self-efficacy) refers to an individual's perception of how easy or difficult it is to perform a certain behaviour (Ajzen 1991; Martín-Peña et al. 2010; Sanchez-Medina et al. 2014). According to Ajzen (1991), PBC reflects past experiences and anticipated barriers and obstacles to performing a specific behaviour. In essence, $\mathrm{PBC}$ is an indication of a person's perception of his or her control over the resources needed to perform the target behaviour (Fielding et al. 2008; Kim \& Chung 2011; MartínPeña et al. 2010).

Psomas et al. (2011) identified factors that make it difficult for business to implement the ISO 14001 environmental management system standard. These included periodic audits, lack of knowledge and experience in environmental management issues, required resources for and time of implementation, keeping and checking records, employee resistance to change, corrective and preventive actions, and training in environmental management issues. Worthington and Patton (2005) cited time, resources, priorities, perception of costs versus benefits and short-term focus as barriers to environmental management system implementation in SMEs. Dahlmann, Brammer and Millington (2008a) found that both internal and external barriers, such as a lack of skilled human resources, financial resources, information, clear regulations and technology, are critical influencers 
of managers' intention and ability to implement an environmental management system.

In this article, PBC will refer to an SME owner's perceptions of the ease or difficulty of implementing an environmental management system. These perceptions will deal with the ability of the business owner to overcome the barriers to implementing an environmental management system. The greater the PBC of the SME owner, the greater the possibility that he and/or she intends to implement an environmental management system. Very few studies directly investigate the relationship between SME owners' PBC over environmental management system implementation and their intention to implement such systems. Schaper (2002) found that the availability of information and time are significantly linked to the green purchase behaviour of SME owners. Similarly, Lopez-Gamero et al. (2011) reported that the availability of complementary resources has a positive influence on managers' perceptions of sustainability as a competitive opportunity. Sanchez-Medina et al. (2014) found that PBC positively influences the SME owners' intention to undertake environmental measures. Thus, the following hypothesis will be tested in this study:

$\mathbf{H}_{3}$ : There is a positive relationship between SME owners' perceived behavioural control and their intention to implement such a system.

Figure 1 shows the theoretical framework that will be used in this study, and includes the four components discussed above, as well as the proposed hypotheses.

The framework in Figure 1 showed that ATT, PN and perceived behaviour control have relationships with the INTENT. This is based on Azjen's theory of planned behaviour. This theory provides empirical evidence to support its propositions. However, the lack of research that applies to SME owners' INTENT necessitates the application of the theory in this context.

\section{Research methodology and design}

A survey was adopted with the aim of collecting data from a large sample and empirically testing the hypotheses. The empirical research was limited to SMEs in the Eastern Cape area of South Africa to ensure that meaningful and accurate data were collected. A questionnaire, together with a covering

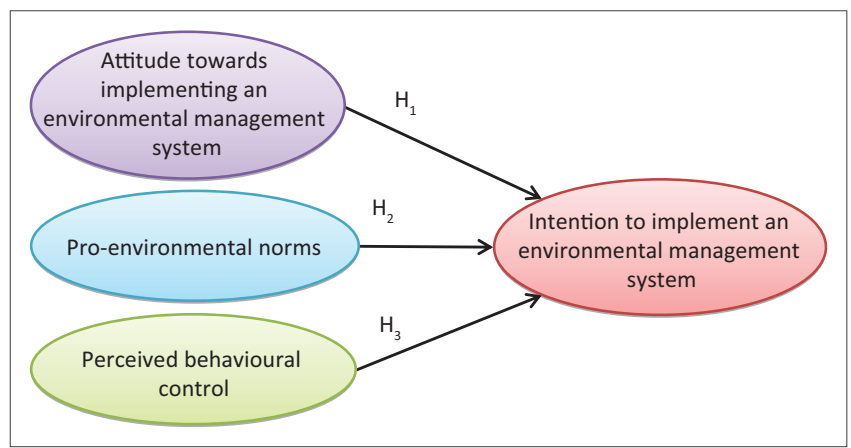

FIGURE 1: Theoretical framework used. letter describing the purpose of the study and a definition of an environmental management system, was distributed to SME owners who had agreed to participate in the study. The questionnaire had two sections. The first section dealt with the background information of the respondents and their businesses, whereas the second section dealt with the variables measuring the four components included in the theoretical framework (Figure 1).

For the purposes of this study, SMEs that employ no more than 200 full-time employees in the Eastern Cape area, were the population from which the sample was drawn. The researcher made use of criterion sampling to select respondents. In this study, the research objectives, the statistical test to be conducted, the traditions of the particular field of study and the resource constraints (cost and time) were considered when choosing a sample size (Collis \& Hussey 2014:198; Daniel 2012:237; Ruben \& Babbie 2012:173; Struwig \& Stead 2013:124). Given these considerations, the researcher decided to target a sample of 500 SMEs in the Eastern Cape. This number takes into consideration both the non-response rate and the response rate (Struwig \& Stead 2013:125).

\section{Measuring instruments}

The questionnaire used to collect the primary data consisted of 28 items to measure the independent and dependent variables in this study. These items were based on an extensive literature review, and consisted of items used in previous studies as well as several self-formulated items. Where necessary the items were contextualised to make them suitable for the present study. All items were anchored on a 5-point Likert scale ranging from 'strongly disagree' to 'strongly agree'.

In the measuring instrument, eight items were used to measure INTENT. These items were mostly based on the entrepreneurial intention scale of Gongxeka (2012) and supplemented with items found in the environmental management literature (Fielding et al. 2008; Greaves et al. 2013; Sanchez-Medina et al. 2014; Venkatesh \& Davis 2000). Five items measured PBC. These items were based on the research of Hillary (2004), McKeiver and Gadenne (2005), Masurel (2007), Kehbila et al. (2009), Gadenne et al. (2009), Dief and Font (2010), Cordano et al. (2010a), Cordano et al. (2010b), Psomas et al. (2011), Brammer et al. (2012) and Uhlaner et.al. (2012). For the PN, six items were used, based on Stern et al. (1999), Hunecke et al. (2001), Heath and Gifford (2002), Steg, Dreijerink and Abrahamse (2005), Lee (2008), Lee (2009), Cordano et al. (2010a) and Cordano et al. (2010b). For the attitude towards environmental management system implementation scale, nine items were used. These items were based on the literature about the outcomes, drivers and benefits of environmental management system implementation (Hillary 2004; Hofmann, Theyel \& Wood 2012; Kehbila et al. 2009; Sanchez-Medina et al. 2014). Table 1 summarises the content of the measuring instrument. 
TABLE 1: Summary of the content of the measuring instrument.

\begin{tabular}{|c|c|c|}
\hline Component & Number of items & Source \\
\hline INTENT & 8 & $\begin{array}{l}\text { Venkatesh and Davis (2000); Fielding et al. } \\
\text { (2008); Gongxeka (2012); Greaves et al. (2013); } \\
\text { Sanchez-Medina et al. (2014) }\end{array}$ \\
\hline ATT & 9 & $\begin{array}{l}\text { Hillary (2004); Kehbila et al. (2009); Hofmann } \\
\text { et al. (2012); Sanchez-Medina et al. (2014) }\end{array}$ \\
\hline PN & 6 & $\begin{array}{l}\text { Stern et al. (1999); Hunecke et al. (2001); } \\
\text { Heath and Gifford (2002); Steg et al. (2005); } \\
\text { Lee (2008); Lee (2009); Cordano et al. (2010a); } \\
\text { Cordano et al. (2010b) }\end{array}$ \\
\hline PBC & 5 & $\begin{array}{l}\text { Hillary (2004); McKeiver and Gadenne (2005); } \\
\text { Masurel (2007); Gadenne et al. (2009); } \\
\text { Kehbila et al. (2009); Cordano et al. (2010a); } \\
\text { Cordano et al. (2010b); Dief and Font (2010); } \\
\text { Psomas et al. (2011); Brammer et al. (2012); } \\
\text { Uhlaner et al. (2012) }\end{array}$ \\
\hline
\end{tabular}

INTENT, intention to implement an environmental management system; PBC, perceived behavioural control; PN, pro-environmental norms; ATT, attitude towards implementing an environmental management system.

To ensure content and face validity of the questionnaire, expert judgement was sought and a pilot study was used. Firstly, the questionnaire was given to four academics in the Department of Business Management at the Nelson Mandela Metropolitan University with experience in both environmental management and the use of the theory of planned behaviour. This process resulted in minor changes being made to the wording of some items. Thereafter, the questionnaire was piloted by 10 SMEs. The completed questionnaires were then subjected to an item analysis to check the internal consistency of the measure. This process yielded satisfactory results to confirm the reliability of the instruments.

\section{Data collection}

The questionnaire was distributed by fieldworkers from the Nelson Mandela Metropolitan University. They initially approached SMEs to ascertain whether they were interested in participating in the study. Consenting SME owners were then provided with a hard copy of the questionnaire, and arrangements were made for the collection of completed questionnaires. In total, 359 questionnaires were returned.

Once the questionnaires had been returned, they were checked for missing data. The examination revealed that 33 questionnaires had missing information for more than three of the items measuring the hypothetical constructs in this study. These questionnaires were deemed unusable and were excluded from the study, giving a total response sample of 326 SME owners. Thus, the effective response rate for this study was $65 \%$, which conforms to Babbie and Mouton's (2001:261) guideline for a good response rate. Given this high response rate, non-response bias was not regarded as a problem in this study. If questionnaires had three or fewer missing values for the hypothetical constructs, and the respondents concerned could not be contacted to obtain the outstanding information, the researcher made use of the mean-substitution approach to remedy the situation. This approach is best suited to situations where the levels of missing values are relatively low, as was the case in this study (Hair et al. 2014:51).

\section{Results Sample description}

The majority of the respondents $(72 \%)$ were males over the age of $40(62 \%)$. More than two-thirds $(68 \%)$ of the respondents had a post-matric qualification and had been running their businesses for more than 5 years (79\%). Of the SMEs that participated in the survey, $57 \%$ were family businesses and $43 \%$ were non-family businesses. Almost half $(49 \%)$ of the businesses were close corporations, $22 \%$ were sole traders and $15 \%$ were private companies. In terms of the number of employees, 46\% employed between 5 and 9 individuals, 28\% employed between 10 and 19 individuals and 16\% employed between 20 and 49 individuals. The majority of the businesses were service providers $(37 \%)$ and $29 \%$ were retailers or wholesalers.

\section{Results of the validity and reliability analyses of the measuring instrument}

To assess the validity of the measuring scales, exploratory factor analysis (EFA) was performed on all of the items in the measuring instrument. Principal component analysis and varimax raw were specified as the extraction and rotation methods. The explained percentage variance and the factor loadings (greater than 0.4) were considered when assessing the validity of the measuring instrument. The type of reliability estimate implemented to assess the internal consistency of the measuring instrument in this study was Cronbach's alpha coefficients. Cronbach's alpha coefficients of greater than 0.7 deemed a scale to be reliable (Nunnally 1978:45). To test the influence of the SME owners' attitude towards an environmental management system, their PN, and the PBC on their INTENT, multiple regression analysis was used.

The results of the EFA and the reliability tests performed on the items in the measuring instrument showed that four factors with eigenvalues greater than 1 were extracted from the data using principle components and varimax raw rotation. These four factors explained $57.2 \%$ of the variance in the data. The first factor extracted, INTENT, explained $22.9 \%$ of the variance in the data. All eight items intended to measure this factor loaded together as expected, with factor loading ranging from 0.875 to 0.686 . This factor returned a Cronbach's alpha coefficient of 0.939 .

The second factor extracted from the data, PBC explained $10.5 \%$ of the variance in the data. All five items intended to measure $\mathrm{PBC}$ loaded together, and factor loadings between 0.802 and 0.528 could be observed for this factor. In addition, PBC returned a Cronbach's alpha coefficient of 0.793 .

The third factor extracted, PN, also explained $10.5 \%$ of the variance in the data. All six items used to measure this factor loaded as expected, and factor loadings of between 0.747 and 0.477 were returned. A Cronbach's alpha coefficient of 0.787 was calculated for PN. 
The last factor extracted, ATT, explained $13.3 \%$ of the variance in the data. All nine items intended to measure this factor loaded together. The factor loadings for ATT ranged between 0.704 and 0.405 . This factor returned a Cronbach's alpha coefficient of 0.860 .

Given these results, the validity and reliability of the dependent and independent variables were confirmed. In addition, as all items loaded as expected, the operational definitions of the variables remained the same.

\section{Descriptive statistics and correlation analysis}

Descriptive statistics were calculated to summarise and organise the sample data. Table 2 contains the means, standard deviations and frequencies for the variables under investigation in this study.

As can be seen from Table 2, the dependent variable, INTENT, returned the second highest mean score of all the variables $(\bar{x}=3.66)$. More than half of the respondents $(52.76 \%)$ agreed that they intended to implement an environmental management system, whereas only $6.13 \%$ indicated that they had no intention of implementing such a system. PN returned the highest mean score of all the variables $(\bar{x}=3.89)$, followed by ATT $(\bar{x}=3.31)$ and PBC $(\bar{x}=3.20)$. The vast majority of the respondents agreed that they possess $\mathrm{PN}$, and only $0.61 \%$ indicated that they did not. In addition, $35.28 \%$ of the respondents had a positive ATT, while the majority, $57.98 \%$, were unsure when evaluating the outcomes of implementing such a system. Lastly, $24.85 \%$ of the respondents agreed with the statements measuring $\mathrm{PBC}$, and $62.88 \%$ were unsure whether or not their businesses were able to implement an environmental management system. Table 3 contains the Pearson product moment correlation coefficients calculated for the dependent and independent variables in this study.

As can be seen from the correlation matrix in Table 3, all the variables were significantly and positively correlated with each other. The dependent variable, INTENT, shows significant positive relationships with the independent

TABLE 2: Descriptive statistics of the results.

\begin{tabular}{llllll}
\hline Variable & Mean & Standard deviation & Disagree (\%) & Neutral (\%) & Agree (\%) \\
\hline INTENT & 3.66 & 0.75 & 6.13 & 41.10 & 52.76 \\
PBC & 3.20 & 0.71 & 12.27 & 62.88 & 24.85 \\
PN & 3.89 & 0.58 & 0.61 & 25.77 & 73.62 \\
ATT & 3.31 & 0.65 & 6.75 & 57.98 & 35.28 \\
\hline
\end{tabular}

INTENT, intention to implement an environmental management system; PBC, perceived behavioural control; PN, pro-environmental norms; ATT, attitude towards implementing an environmental management system.

TABLE 3: Pearson product moment correlations $(N=326)$

\begin{tabular}{lllllll}
\hline Variable & Means & Standard deviation & INTENT & PBC & PN & ATT \\
\hline INTENT & 3.664 & 0.749 & 1.000 & - & - & - \\
PBC & 3.201 & 0.714 & $0.445 * \dagger$ & 1.000 & - & - \\
PN & 3.891 & 0.583 & $0.489 * \dagger$ & $0.412 * \dagger$ & 1.000 & - \\
ATT & 3.314 & 0.647 & $0.634 * \dagger$ & $0.562 * \dagger$ & $0.462 * \dagger$ & 1.000 \\
\hline
\end{tabular}

*, correlations are significant at $p<0.05 ; \dagger$, moderate correlation; $\$$, large correlation. INTENT, intention to implement an environmental management system; PBC, perceived behavioural control; PN, pro-environmental norms; ATT, attitude towards implementing an environmental management system. variables. PBC $(r=0.445)$ and PN $(r=0.489)$ had a moderate correlation with intention to implement and environmental management system. However, attitude towards an environmental management system $(r=0.634)$ had a strong correlation with INTENT. PBC had a moderate relationship with PN ( $r=0.412)$ and a large relationship with attitude towards an environmental management system $(r=0.562)$. Finally, PN showed a moderate relationship with attitude towards an environmental management system $(r=0.462)$.

\section{Regression analysis to test the hypotheses}

To test the hypotheses in this study, regression analysis was undertaken. The results of this analysis are presented in Table 4. A common problem in regression analysis is multicollinearity. Multi-collinearity exists when the independent variables in the regression analysis are correlated and could thus influence the ability of these variables to accurately explain the variance in the dependent variable (Hair et al. 2014:161) Thus variance inflation factors (VIFs) were calculated to assess whether multi-collinearity could affect the results of the regression analysis.

Table 4 shows that all the independent variables returned VIFs below 4 (equivalent to a tolerance of 0.25 ), which mean that multi-collinearity does not pose a problem in this study ( $\mathrm{O}^{\prime}$ Brien 2007:674). Furthermore, the overall regression model was significant $(F=89.502 ; p<0.000)$ and the independent variables explained $45.47 \%$ of the variance in INTENT $\left(R^{2}=0.4547\right)$. Two of the independent variables had a significant positive influence on INTENT. Attitude towards an environmental management system $\left(b^{*}=0.481769 ; p=0.000000\right)$ had the greatest influence on INTENT, followed by PN $\left(b^{*}=0.234338 ; p=0.000001\right)$. PBC did not have a significant influence on INTENT $\left(b^{*}=0.078014\right.$; $p=0.125989)$. Given that the $p$-values for the influence of the SME owners' attitude towards an environmental management system and PN on the INTENT is less than 0.05 hypotheses $\mathrm{H}_{1}$ and $\mathrm{H}_{2}$ are accepted. However, because the $p$-value for the influence of $\mathrm{PBC}$ is greater than $0.05 \mathrm{H}_{3}$ is rejected.

\section{Discussion}

The findings of this study revealed that the majority of the respondents agreed that they intended to implement an environmental management system, and exhibited PN. However, most of the respondents returned a neutral response to theitems measuring their attitude towards an environmental

TABLE 4: Influence of independent variables on intention to implement an environmental management system $(N=326)$.

\begin{tabular}{llllllll}
\hline $\begin{array}{l}\text { Independent } \\
\text { variables }\end{array}$ & $\mathbf{b}^{*}$ & $\begin{array}{l}\text { Standard } \\
\text { error }\end{array}$ & $\mathbf{b}$ & $\begin{array}{l}\text { Standard } \\
\text { error }\end{array}$ & T(322) & $p$-value & VIF \\
\hline Intercept & - & - & 0.400 & 0.226 & 1.765 & 0.079 & - \\
ATT & 0.482 & 0.052 & 0.557 & 0.060 & 9.222 & 0.000 & 1.612 \\
PN & 0.234 & 0.047 & 0.301 & 0.061 & 4.940 & 0.000 & 1.329 \\
PBC & 0.078 & 0.051 & 0.082 & 0.053 & 1.534 & 0.126 & 1.527 \\
\hline
\end{tabular}

INTENT, intention to implement an environmental management system; $\mathrm{PBC}$, perceived behavioural control; PN, pro-environmental norms; ATT, attitude towards implementing an environmental management system; $b$, beta coefficient; $b^{*}$, standardised beta coefficient; $\mathrm{VIF}$, variance inflation factor.

$R=0.67431858 ; R^{2}=0.45470555 ;$ adjusted $R^{2}=0.44962517 ; F(3,322)=89.502 ; p<0.0000 ;$ Standard error of estimate $=0.55559$. 
management system and PBC. In addition, the results of the correlation analysis revealed that all the variables under investigation were significantly and positively related to one another. This finding confirms Ajzen's (1991) assertion that all variables in the theory of planned behaviour are correlated.

The results of the regression analysis showed that the SME owners' attitude towards an environmental management system and PN have significant positive influence on their INTENT. In other words, the more positive the owners' attitude towards an environmental management system, and the more PN they exhibit, the greater their INTENT. These findings are supported by the studies of Cordano et al. (2010a) and Sanchez-Medina et al. (2014) who both found significant positive relationship between attitude towards environmental management and the adoption of such practices. In addition, the studies of Dief and Font (2010), Lopez-Gamero et al. (2011) and Sanchez-Medina et al. (2014) provide support for the significant positive influence of PN on the INTENT. However, the results also show that PBC does not influence SME owners' INTENT. This finding is in contrast with the results of Sanchez-Medina et al. (2014) who found PBC to positively influence INTENT. Thus, when using the theory of planned behaviour to understand why SME owners intend to implement environmental management systems, there are only two components that have proved useful in this study, SME owners' attitude towards an environmental management system and PN.

\section{Conclusions and implications}

Increased concern about the natural environment has put pressure on all businesses to reduce their environmental impact. This has prompted many businesses to implement an environmental management system. Given the prominence of SMEs in most economies, and their potential environmental impact, it is important to examine the factors that lead these businesses to implement an environmental management system. However, research focused on understanding why SMEs adopt such systems is lacking. An important starting point for SMEs to adopt an environmental management system is the psychological predispositions of their owners. Thus, this study adapted the theory of planned behaviour to explain SME owners' INTENT.

Given the fact that attitude towards an environmental management system significantly influences the intention to adopt such a system, it is recommended that individuals or organisations that advocate the use of environmental management systems highlight the positive outcomes that such systems could have on SMEs. In addition, the positive influence of PN should be harnessed to encourage the implementation of environmental management systems. In other words, the implementation of environmental management systems should be seen as a personal and moral obligation, and thus as vital to the legitimacy of SMEs.

The findings of this study also show that PBC does not have a significant influence on the INTENT and is thus not part of the proposed framework.

\section{Acknowledgements Competing interests}

The authors declare that they have no financial or personal relationships that may have inappropriately influenced them in writing this article.

\section{Authors' contributions}

Both authors contributed equally in compiling the final manuscript.

\section{References}

Ajzen, I., 1991, 'The theory of planned behavior', Organizational Behavior and Human Decision Process 50, 179-211. https://doi.org/10.1016/0749-5978(91)90020-T

Babbie, E. \& Mouton, J., 2001, The practice of social research, Oxford University Press, Cape Town.

Boiral, O., Baron, C. \& Gunnlaugson, O., 2014, 'Environmental leadership and consciousness development: A case study among Canadian SMEs', Journal of Business Ethics 123(3), 363-383. https://doi.org/10.1007/s10551-013-1845-5

Bos-Brouwers, H.E.J., 2010, 'Corporate sustainability and innovation in SMEs: Evidence of themes and activities in practice', Business Strategy and the Environment 19, 417-435.

Brammer, S., Hoejmose, S. \& Marchant, K., 2012, 'Environmental management in SMEs in the UK: Practices, pressures and perceived benefits', Business Strategy and the Environment 21, 423-434. https://doi.org/10.1002/bse.717

Chao, Y., 2012, 'Predicting people's environmental behaviour: Theory of planned behaviour and model of responsible environmental behaviour' Environmental Education Research 18(4), 437-461. https://doi.org/10.1080/13504622.2011. 634970

Collis, J. \& Hussey, R., 2014, Business research: A practical guide for undergraduate and postgraduate students, 4th edn., Palgrave Macmillan, Hampshire.

Cordano, M., Marshall, R.S. \& Silverman, M., 2010a, 'How do small and medium enterprises go "green"? A study of environmental management programs in the U.S. wine industry', Journal of Business Ethics 92(3), 463-478. https://doi. org/10.1007/s10551-009-0168-z

Cordano, M., Welcomer, S., Scherer, R., Pradenas, L. \& Parada, V., 2010b, 'Understanding cultural differences in the antecedents of pro-environmental behavior: A comparative analysis of business students in the United States and Chile', The Journal of Environmental Education 41(4), 224-238. https://doi.org/ 10.1080/00958960903439997

Dahlmann, F., Brammer, S. \& Millington, A., 2008a, 'Barriers to proactive environmental management in the United Kingdom: Implications for business and public policy', Journal of General Management 33(3), 1-21. https://doi.org/10.1177/030630 700803300301

Dahlmann, F., Brammer, S. \& Millington, A., 2008b, 'Environmental management in the United Kingdom: New survey evidence', Management Decision 46(2), 264-283. https://doi.org/10.1108/00251740810854159

Daniel, J., 2012, Sampling essentials: Practical guidelines for making sampling choices, Sage, Thousand Oaks, CA.

Darnall, N., Jolley, G.J. \& Handfield, R., 2008, 'Environmental management systems and green supply chain management: Complements for sustainability?', Business Strategy and the Environment 18, 30-45. https://doi.org/10.1002/bse.557

Dief, M.E. \& Font, X., 2010, 'Determinants of environmental management in the red sea hotels: Personal and organizational values and contextual variables', Journal
of Hospitality and Tourism Research 36(1), 115-137. https://doi.org/10.1177/ of Hospitality and
1096348010388657

Dietz, T., Fitzgerald, A. \& Shwom, R., 2005, 'Environmental values', Annual Review of Environment and Resources 30(1), 335-372. https://doi.org/10.1146/annurev. Environment and Resources
energy.30.050504.144444

Dunphy, D., Griffiths, A. \& Benn, S., 2007, Organizational change for corporate sustainability: A guide for leaders and change agents of the future, Routledge, London.

Fielding, K.S., McDonald, R. \& Louis, W.R., 2008, 'Theory of planned behaviour, identity and intentions to engage in environmental activism', Journal of Environmental Psychology 28(4), 318-326. https://doi.org/10.1016/j.jenvp.2008. 03.003

Fishbein, M., \& Ajzen, I., 1975, Belief attitude, intention and behaviour, AddisonWesley, Reading, MA.

Fritsche, I., Jonas, E., Kayser, D.N. \& Koranyi, N., 2010, 'Existential threat and compliance with pro-environmental norms', Journal of Environmental Psychology 30(1), 67-79. https://doi.org/10.1016/j.jenvp.2009.08.007

Gadenne, D.L., Kennedy, J. \& McKeiver, C., 2009, 'An empirical study of environmental awareness and practices in SMEs', Journal of Business Ethics 84(1), 45-63. https:// doi.org/10.1007/s10551-008-9672-9

Gongxeka, V., 2012, 'Employee perceptions of self-employment', Unpublished masters dissertation, Nelson Mandela Metropolitan University, Port Elizabeth. 
Greaves, M., Zibarras, L.D. \& Stride, C., 2013, 'Using the theory of planned behavior to explore environmental behavioral intentions in the workplace', Journal of Environmental Psychology34,109-120. https://doi.org/10.1016/j.jenvp.2013.02.003

Groepe, F., 2015, The role of small business in the economy, viewed 29 July 2016, from https://www.resbank.co.za/Lists/Speeches/Attachments/452/Role\%20of\%20 small\%20business $\% 202015 \% 20$.pdf

Hair, J.F., Black, W.C., Babin, B.J. \& Anderson, R.E., 2014, Multivariate data analysis, 7th edn., Pearson, Harlow.

Heath, Y. \& Gifford, R., 2002, 'Extending the theory of planned behavior: Predicting the use of public transportation', Journal of Applied Social Psychology 32(10), 2154-2189. https://doi.org/10.1111/j.1559-1816.2002.tb02068.x

Hillary, R., 2004, 'Environmental management systems and the smaller enterprise', Journal of Cleaner Production 12(6), 561-569. https://doi.org/10.1016/j.jclepro. 2003.08.006

Hofmann, K.H., Theyel, G. \& Wood, C.H., 2012, 'Identifying firm capabilities as driver of environmental management and sustainability practices - Evidence from SME manufacturers', Business Strategy and the Environment 21, 530-545. https://doi. org/10.1002/bse.739

Holliday, C.O., Schmidheiny, S. \& Watts, P., 2002, Walking the talk: The business case for sustainable development, Greenleaf, Sheffield.

Hunecke, M., Blobaum, A., Matthies, E. \& Hoger, R., 2001, 'Responsibility and environment: Ecological norm orientation and external factors in the domain of travel mode choice behavior', Environment and Behavior 33(6), 830-852. https:// doi.org/10.1177/00139160121973269

Kehbila, A.G., Jurgen, E. \& Brent, A.C., 2009, 'Strategic corporate environmental management within the South African automotive industry: Motivations, benefits, hurdles', Corporate Social Responsibility and Environmental Management 16, 310-323. https://doi.org/10.1002/csr.188

Kim, H.Y. \& Chung, J.E., 2011, 'Consumer purchase intention for organic personal care products', Journal of Consumer Marketing 28(1), 40-47. https://doi.org/10.1108/ 07363761111101930

Klewitz, J. \& Hansen, E.G., 2013, 'Sustainability-oriented innovation of SMEs: Systematic review', Journal of Cleaner Production 65, 57-75. https://doi.org/ 10.1016/j.jclepro.2013.07.017

Laszlo, C., 2003, The sustainable company: How to create lasting value through socia and environmental performance, Island Press, Washington, DC.

Lee, K., 2008, 'Opportunities for green marketing: Young consumers', Marketing Intelligence \& Planning 26(6), 573-586. https://doi.org/10.1108/02634500810902839

Lee, K., 2009, 'Gender differences in Hong Kong adolescent consumers' green purchasing behavior', Journal of Consumer Marketing 26(2), 87-96. https://doi. purchasing behavior', Journal of Con

Lopez-Gamero, M.D., Claver-Cortes, E. \& Molina-Azorin, J.F., 2011, 'Environmenta perception, management, and competitive opportunity in Spanish hotels', Cornell Hospitality Quarterly 52(4), 480-500. https://doi.org/10.1177/1938965511420694

Martín-Peña, M.L., Díaz-Garrido, E. \& Sánchez-López, J.M., 2010, 'Relation between management's behavioural intentions toward the environment and environmental actions', Journal of Environmental Planning and Management 53(3), 297-315. https://doi.org/10.1080/09640561003612866
Masurel, E., 2007, 'Why SMEs invest in environmental measures: Sustainability evidence from SME printing firms', Business Strategy and the Environment 16(3), 190-201. https://doi.org/10.1002/bse.478

McKeiver, C. \& Gadenne, D., 2005, 'Environmental management systems in small and medium businesses', International Small Business Journal 23(5), 513-537. https:// doi.org/10.1177/0266242605055910

Monroe, M.C., 2003, 'Two avenues for encouraging conservation behaviors', Research in Human Ecology 10(2), 113-125.

Nee, G.Y. \& Wahid, N.A., 2010, 'The effect of ISO 14001 environmental management system implementation on SMEs performance: An empirical study in Malaysia', Journal of Sustainable Development 3(2), 215-220.

Nunnally, J.C., 1978, Psychometric theory, 2nd edn., McGraw-Hill, New York.

O'Brien, R.M., 2007, 'A caution regarding rules of thumb for variance inflation factors', Quality and Quantity 41, 673-690.

Psomas, E.L., Fotopoulos, C.V. \& Kafetzopoulos, D.P., 2011, 'Motives, difficulties and benefits in implementing the ISO 14001 environmental management system, Management of Environmental Quality: An International Journal 22(4), 502-521. https://doi.org/10.1108/14777831111136090

Ruben, A. \& Babbie, E., 2012, Essential research methods for social work, Cengage, Belmont, CA.

Sanchez-Medina, A.J., Romero-Quintero, L. \& Sosa-Cabrera, S., 2014, 'Environmental management in SME companies: An analysis from the perspective of the theory of planned behavior', PLOS One 9(2), 1-12. https://doi.org/10.1371/journal. pone.0088504

Schaper, M., 2002, 'Small firms and environmental management: Predictors of green purchasing in Western Australian pharmacies', International Small Business Journal 20(3), 235-251. https://doi.org/10.1177/0266242602203001

Schwartz, S.H., 1977, 'Normative influences on altruism', Advances in Experimental Social Psychology 10, 221-79. https://doi.org/10.1016/S0065-2601(08)60358-5

Steg, L., Dreijerink, L. \& Abrahamse, W., 2005, 'Factors influencing the acceptability of energy policies: A test of VBN theory', Journal of Environmental Psychology 25(4), 415-425. https://doi.org/10.1016/j.jenvp.2005.08.003

Steg, L. \& Vlek, C., 2009, 'Encouraging pro-environmental behaviour: An integrative review and research agenda', Journal of Environmental Psychology 29(3), 309317. https://doi.org/10.1016/j.jenvp.2008.10.004

Stern, P.C., Dietz, T., Abel, T., Guagnano, G.A. \& Kalof, L., 1999, 'A value-belief-norm theory of support for social movements: The case of environmentalism', Human Ecology Review 6(2), 81-97.

Struwig, F.W. \& Stead, G.B., 2013, Research: Planning, designing and reporting, Pearson, Cape Town.

Uhlaner, L.M., Berent-Braun, M.M., Jeurissen, R.J.M. \& De Wit, G., 2012, 'Beyond size: Predicting engagement in environmental management practices of Dutch SMEs', Journal of Business Ethics 109, 411-429. https://doi.org/10.1007/s10551-011-1137-x

Venkatesh, V. \& Davis, F.D., 2000, 'A theoretical extension of the technology acceptance model: Four longitudinal field studies', Management Sciences 46(2), 186-204. https://doi.org/10.1287/mnsc.46.2.186.11926

Worthington, I. \& Patton, D., 2005, 'Strategic intent in the management of the green environment within SMEs', Long Range Planning 38(2), 197-212. https://doi. org/10.1016/j.Irp.2005.01.001 